\title{
Exposure of Staphylococcus aureus to silver(I) induces a short term protective response
}

\author{
Alanna Smith • Raymond Rowan • \\ Malachy McCann • Kevin Kavanagh
}

Received: 28 February 2012/ Accepted: 17 April 2012/Published online: 26 April 2012

(c) Springer Science+Business Media, LLC. 2012

\begin{abstract}
The $\operatorname{Ag}(\mathrm{I})$ ion has well established antibacterial and antifungal properties. Exposure of Staphylococcus aureus to $\mathrm{MIC}_{80} \mathrm{AgNO}_{3}(3 \mu \mathrm{g} / \mathrm{ml})$ lead to an increase in the activity of superoxide dismutase, glutathione reductase and catalase at $30 \mathrm{~min}$ but activity declined by $60 \mathrm{~min}$. In addition, exposure of cells to this metal ion for $1 \mathrm{~h}$ lead to increased expression of a number of proteins such as elongation factors $\mathrm{Ts}$, Tu and $\mathrm{G}$, fructose-bisphosphate aldolase and triosephosphate isomerase but their expression declined following $4 \mathrm{~h}$ exposure. ATP binding cassette transporter protein and oligoendopeptidase F showed increased expression at $4 \mathrm{~h}$. While $\operatorname{Ag}(\mathrm{I})$ is a potent antimicrobial agent this work demonstrates that $S$. aureus can mount a short-term protective response to exposure to the metal ion but that this is eventually overcome.
\end{abstract}

Keywords Antimicrobial - Silver(I) . Staphylococcus $\cdot$ Proteomics $\cdot$ Oxidative stress

A. Smith · R. Rowan · K. Kavanagh $(\bowtie)$

Medical Mycology Unit, NICB, Department of Biology, National University of Ireland Maynooth, Maynooth, Co. Kildare, Ireland

e-mail: kevin.kavanagh@nuim.ie

A. Smith · R. Rowan - M. McCann Department of Chemistry, National University of Ireland Maynooth, Maynooth, Co. Kildare, Ireland

\section{Introduction}

Silver has well characterised antimicrobial properties and $\operatorname{Ag}(\mathrm{I})$ ions are active against a wide range of bacteria, fungi and viruses at concentrations of $10^{-9}$ to $10^{-6} \mathrm{M}$ (Percival et al. 2005). The $\mathrm{Ag}(\mathrm{I})$ ion is the active agent in many healthcare products such as silver-coated catheters (Dasgupta 1994), wound dressings (Adams et al. 1999; Monafo and Freedman 1987) and creams for the treatment of burns (Wright et al. 1998). Clinical investigations into the anti-bacterial nature of silver-containing dressings have revealed the potent activity of these materials against Pseudomonas aeruginosa (Ulker et al. 2005; Olsen et al. 2000), while the effective anti-bacterial activity of the dressings was also demonstrated against methicillin resistant Staphylococcus aureus and vancomycinresistant Pseudomonas species. Central venous catheters impregnated with silver metal particles substantially reduce the incidence of catheter-associated infections in paediatric patients (Carbon et al. 1999).

Although the mechanism(s) by which silver kills cells is not fully understood (Lok et al. 2006) there have been many suggestions regarding its mode of action. $\operatorname{Ag}(\mathrm{I})$ ions interact with thiol groups of the L-cysteine residue of proteins (Park et al. 2009; Cortese-Krott et al. 2009; Atiyeh et al. 2007; Castellano et al. 2007). This inactivates enzymatic functions involved in the respiratory chain such as NADH and succinate dehydrogenase which can impede electron transfer (Park et al. 2009). Another mechanism of 
action involves the generation of reactive oxygen species (ROS) (Park et al. 2009; Cortese-Krott et al. 2009) which induces oxidative stress (Park et al. 2009) and leads to protein and DNA degradation (Park et al. 2009; Atiyeh et al. 2007; Castellano et al. 2007). Exposing the yeast Candida albicans to $\mathrm{Ag}(\mathrm{I})$ ions activates the Cap1p and Hog1p pathways as a consequence of oxidative and/or osmotic stress (Rowan et al. 2010).

Staphylococcus aureus, has the ability to survive in nutrient-limiting and stressful conditions (Clements et al. 1999), which contribute to its infectious nature. Approximately $30 \%$ of healthy individuals carry $S$. aureus in the anterior nares (García-Lara et al. 2005), but once it contaminates a skin breach it can result in a variety of skin infections, ranging from superficial infections such as impetigo to more serious diseases such as toxic shock syndrome and sepsis (Pichon and Felden 2005). Treatment of S. aureus infections is complicated by the emergence of methicillin-resistant $S$. aureus (MRSA) and it is due to the increasing incidence of resistance to conventional antimicrobials that there has been a renewed interest in the use of $\operatorname{Ag}(\mathrm{I})$ as an antimicrobial agent (CorteseKrott et al. 2009).

The aim of the work presented here was to ascertain the response of $S$. aureus to $\mathrm{Ag}(\mathrm{I})$ ions and to determine whether the bacterial cells were capable of mounting a response to withstand the antimicrobial effects of the metal cation.

\section{Materials and methods}

Organism and culture conditions

A clinical $S$. aureus urinary tract infection isolate was used. Cultures were grown on nutrient agar plates (Oxoid Ltd., Basingstoke, England) at $37{ }^{\circ} \mathrm{C}$ for $24 \mathrm{~h}$ and kept at $4{ }^{\circ} \mathrm{C}$ for short-term storage. Bacterial strains were cultured overnight in nutrient broth (Oxoid Ltd.) in an aerated conical flask in an orbital shaker at $37{ }^{\circ} \mathrm{C}$ and $200 \mathrm{rpm}$.

\section{Susceptibility assay}

Bacteria cultured to the stationary phase $\left(\mathrm{OD}_{600 \mathrm{~nm}}\right.$ of 2) overnight in nutrient broth, were diluted to an absorption value of 0.1 at $600 \mathrm{~nm}$. To each well of a 96-well round-bottomed plate, $100 \mu \mathrm{l}$ of fresh nutrient broth medium was added. From a stock solution of $\mathrm{AgNO}_{3}$ (Aldrich) $(200 \mu \mathrm{g} / \mathrm{ml}), 100 \mu \mathrm{l}$ was added to each well and a serial dilution was carried out across the plate. Cells $(100 \mu \mathrm{l})$ were added to each well and the plates were incubated at $37^{\circ} \mathrm{C}$ for $24 \mathrm{~h}$. The $\mathrm{OD}_{540 \mathrm{~nm}}$ of the cultures was determined using a microplate reader (Bio-Tek, Synergy HT). All susceptibility assays were performed on three separate occasions. The $\mathrm{MIC}_{80}$ (Minimum Inhibitory Concentration) was defined as the concentration of compound that inhibited the growth of the bacteria by $80 \%$.

Enzymatic activity assays

Glutathione reductase activity was measured according to the method of Foster and Hess (1980). The reaction was followed by a reduction in the absorption at $340 \mathrm{~nm}$ on a Cary IE UV-Visible spectrophotometer, using an extinction coefficient value of $6.22 \mathrm{mM}^{-1} \mathrm{~cm}^{-1}$ for NADPH. Superoxide dismutase (SOD) activity of silver $\mathrm{Ag}(\mathrm{I})$-treated $S$. aureus cells was quantified using a SOD Assay kit (Sigma Aldrich Ltd.). The SOD activity was determined at $450 \mathrm{~nm}$ using a microplate reader. Catalase activity was measured using the method described by Larsen and White (1995). Protein extract (100 $\mu \mathrm{l}, 250 \mu \mathrm{g} / \mathrm{ml})$ was added to $1.8 \mathrm{ml}$ of $17 \mathrm{mM} \mathrm{H}_{2} \mathrm{O}_{2}$ in a sterile tube. The suspension was centrifuged at $10,000 \times g$ (Eppendorf centrifuge 5417R) for $1 \mathrm{~min}$ to stop the reaction. The supernatant was removed and dispensed into a quartz cuvette where the absorbance at $240 \mathrm{~nm}$ was read using a Beckman DU640 spectrophotometer. The blank consisted of $17 \mathrm{mM} \mathrm{H}_{2} \mathrm{O}_{2}$.

Whole cell protein extraction from S. aureus

Staphylococcus aureus cells were exposed to the $\mathrm{Ag}(\mathrm{I})$ ions and harvested using a Beckmann GS-6 centrifuge for $10 \mathrm{~min}$ at $1,814 \times \mathrm{g}$. The cell pellet was washed twice with sterile phosphate buffer saline (PBS) and re-suspended in $2 \mathrm{ml}$ of Lambert's breaks buffer (10 mM KCl (Sigma-Aldrich), $3 \mathrm{mM} \mathrm{NaCl}$ (Sigma-Aldrich), $4 \mathrm{mM} \mathrm{MgCl}_{2}$ (Sigma-Aldrich), $10 \mathrm{mM}$ 1,4-piperazinedietansulphonic acid (PIPES) (Sigma-Aldrich)). Protease inhibitors (Leupeptin, Pepstatin A, Aprotinin and $N$ - $\alpha$ - $p$-tosyl-L-lysine chloromethylketone hydrochloride (TLCK)), at a concentration of $10 \mu \mathrm{g} / \mathrm{ml}$, were used. Acid-washed glass 
beads (Sigma-Aldrich) were added and the suspension was vortexed on ice for $5 \mathrm{~min}$. The resulting suspension was centrifuged in a Beckmann GS-6 Centrifuge for $5 \mathrm{~min}$ at $454 \times g$, and the resulting supernatant was centrifuged on an Eppendorf 5417R centrifuge at $239 \times g$ for $4 \min$ at $4{ }^{\circ} \mathrm{C}$.

\section{Separation of proteins by 2D SDS-PAGE}

$\mathrm{AgNO}_{3}$ at the $\mathrm{MIC}_{80}$ concentration $(3 \mu \mathrm{g} / \mathrm{ml})$ was added to cultures of $S$. aureus $\left(\mathrm{OD}_{600 \mathrm{~nm}}=2.0\right)$ and the cultures were then grown for pre-determined times. Cells were harvested and whole cell protein was extracted as described. Protein concentration was determined using the Bradford reagent (Bio-Rad, Munich, Germany). Protein was precipitated by the addition of ice-cold acetone. The precipitated protein was collected by centrifugation on an Eppendorf $5417 \mathrm{R}$ centrifuge $\left(17,949 \times \mathrm{g}\right.$ for $30 \mathrm{~min}$ at $\left.4{ }^{\circ} \mathrm{C}\right)$ allowed to air dry. Protein $(300 \mu \mathrm{g})$ was separated by 2D SDS-PAGE as previously described (Kelly and Kavanagh 2010).

LC/MS mass spectrometric analysis of S. aureus proteins

Protein spots that exhibited altered intensities between control and $\mathrm{Ag}(\mathrm{I})$-treated cells were excised, washed and trypsin digested as described (Shevchenko et al. 2006). Samples were analysed on a 6340 Ion Trap LC/ MS spectrometer (Agilent Technologies) using bovine serum albumin as the external standard. The mass lists were generated using the search programme http:// www.matrixscience.com and were blasted using the http://expasy.org/sprot/ search programme. Mascot score values greater than 68 were considered significant at $p<0.05$.

Statistics

All experiments were performed on three separate occasions. Multiple comparisons of means were analysed using Fisher's least significant difference test using PROC GLM of the SAS 9.1 statistical model. Differences were deemed significant with $p \leq 0.05$.

\section{Results}

Response of $S$. aureus to silver nitrate

Staphylococcus aureus cells were exposed to a range of concentrations of $\operatorname{Ag}(\mathrm{I})$ ions and the effect on growth was monitored. At a concentration of $0.78 \mu \mathrm{g} / \mathrm{ml}(4.6 \mu \mathrm{M})$ growth was reduced by $50 \%$ and at $3 \mu \mathrm{g} / \mathrm{ml}(17.7 \mu \mathrm{M})$ growth was inhibited was $80 \%$ (data not presented). Based on these results $3 \mu \mathrm{g} / \mathrm{ml}$ was chosen as the $\mathrm{MIC}_{80}$ value and this was used in subsequent experiments.

Changes in enzymatic activity following exposure to silver nitrate

The activity of SOD, GLR and catalase was measured in cells exposed to $\mathrm{AgNO}_{3}$. When $\mathrm{S}$. aureus cells were exposed to $\mathrm{Ag}(\mathrm{I})$ ions $(17.7 \mu \mathrm{M})$ SOD activity increased after 30 and $60 \mathrm{~min}$ in comparison to the control (Fig. 1A).
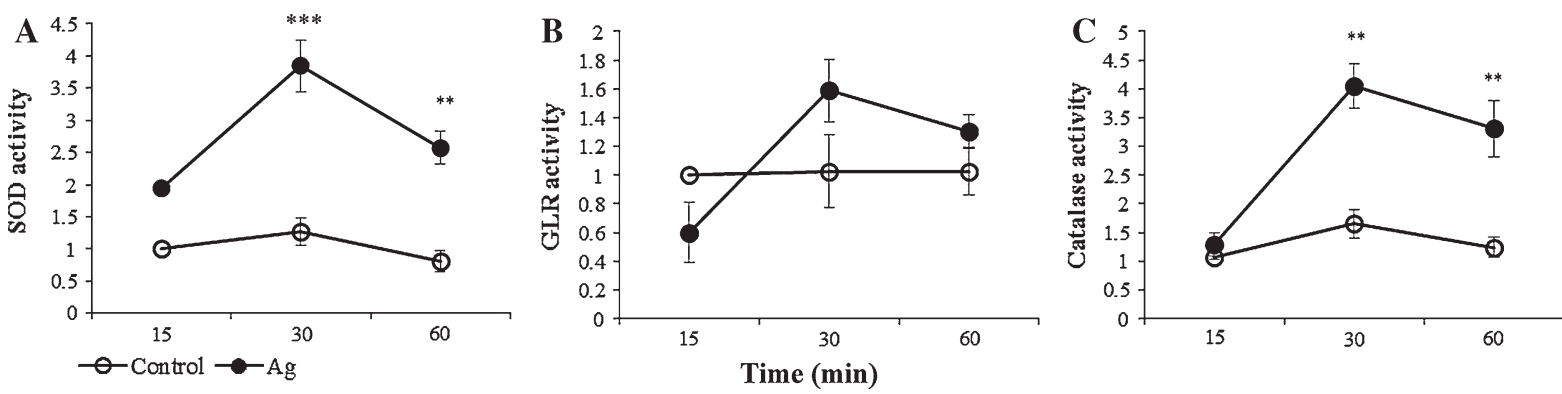

Fig. 1 Activity of A superoxide dismutase, B glutathione reductase and $\mathbf{C}$ catalase following exposure of $S$. aureus to $\mathrm{Ag}(\mathrm{I})$ ions. S. aureus cells were treated with the $\mathrm{MIC}_{80}$ value of $\mathrm{Ag}(\mathrm{I})$ ions for 15, 30 and $60 \mathrm{~min}$, protein was extracted from the cells and enzymatic activity assessed as described. Differences in activity were deemed statistically significant at $* p<0.05$, ${ }^{* *} p<0.01$ and $* * * p<0.001$ 
For $S$. aureus cells exposed to $\operatorname{Ag}(\mathrm{I})$ ions there was a small but statistically insignificant increase in GLR activity at 30 and $60 \mathrm{~min}$ (Fig. 1B) compared to the control.

Catalase activity was measured in $\operatorname{Ag}(\mathrm{I})$-treated $S$. aureus cells and compared to untreated control cells. A significant increase in activity was observed after $30 \mathrm{~min}$ and $60 \mathrm{~min}$ (Fig. 1C). These findings indicate that when S. aureus is exposed to $\mathrm{Ag}(\mathrm{I})$ ions at a concentration of $17.7 \mu \mathrm{M}$, there is an increase in the activity of three antioxidant enzymes which have the capacity to reduce the oxidative damage inflicted by exposure to the $\operatorname{Ag}(\mathrm{I})$ ions.

Changes in protein expression following exposure to silver nitrate

Cells were exposed to $\mathrm{Ag}(\mathrm{I})$ ions $(17.7 \mu \mathrm{M})$ and whole cell protein was extracted, resolved by 2D electrophoresis (Fig. 2) and peptide spots were identified using LC/MS analysis (Table 1). A total of 11 proteins were observed to be altered in expression following exposure of S. aureus to the $\mathrm{Ag}(\mathrm{I})$ salt for $1 \mathrm{~h}$. Eight of these proteins were identified as having putative roles in metabolism, two were involved in virulence and one was known to be associated with the stress response of
S. aureus. Proteins such as elongation factors $\mathrm{Ts}, \mathrm{Tu}$ and $\mathrm{G}$ (spots 236, 155 and 78, respectively), ornithine carbamoyltransferase (spot 237), dihydrolipoamide dehydrogenase (spot 147), fructose-bisphosphate aldolase (spot 314), 30S ribosomal protein S3 (spot 333) and triosephosphate isomerase (spot 340), play roles in metabolism. Proteins possibly associated with the virulence of $S$. aureus included an ATP binding cassette (ABC) transporter protein (spot 294) and also the phosphoserine $46 \mathrm{Hpr}$ protein (spot 417). Oligoendopeptidase $\mathrm{F}$ (spot 111) is known to be involved in the stress response of $S$. aureus.

\section{Discussion}

An increase in SOD activity was observed following exposure of $S$. aureus cells to $\mathrm{Ag}(\mathrm{I})$ ions with the most significant increase in activity (3.8 \pm 0.4 -fold increase, $p<0.001$ ) being observed at $30 \mathrm{~min}$. Catalase activity increased at both the 30 and $60 \mathrm{~min}$ time points, with the most significant being at $30 \mathrm{~min}$ $(4.1 \pm 0.4$-fold, $p<0.01)$. The elevation in enzymatic activity at 30 min may be evidence of an initial response to oxidative stress by the bacterium, and the
Fig. 2 Reference 2D gel for proteomic analysis. Progenesis SameSpot ${ }^{\mathrm{TM}}$ software reference image. Protein spots were analysed for fold changes in comparison to untreated cells, using Progenesis SameSpot ${ }^{\text {M }}$ software. Protein spots were extracted for identification using LC/MS

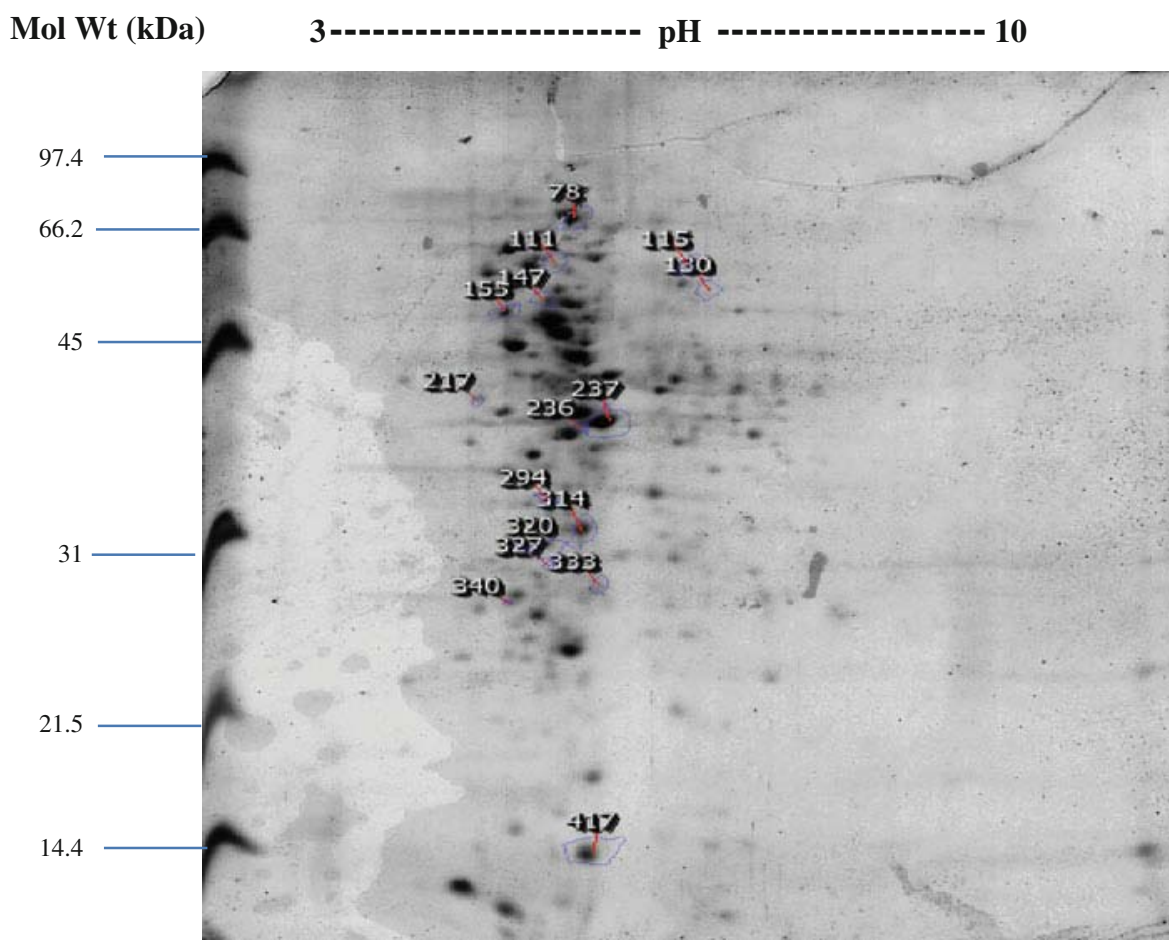


Table 1 Identity of peptides showing alteration in expression following exposure of $S$. aureus to $\mathrm{Ag}(\mathrm{I})$ ions for 1 or $4 \mathrm{~h}$

\begin{tabular}{|c|c|c|c|c|c|c|c|c|}
\hline \multirow[t]{2}{*}{$\begin{array}{l}\text { Spot } \\
\text { no. }\end{array}$} & \multirow[t]{2}{*}{ Accession no. } & \multirow[t]{2}{*}{ Protein } & \multirow[t]{2}{*}{ Function } & \multirow[t]{2}{*}{ Score } & \multirow[t]{2}{*}{$\begin{array}{l}\% \\
\text { Coverage }\end{array}$} & \multicolumn{2}{|c|}{$\begin{array}{l}\text { Fold } \\
\text { changes }\end{array}$} & \multirow[t]{2}{*}{$\begin{array}{l}\text { Expectation } \\
(p) \text { value }\end{array}$} \\
\hline & & & & & & $1 \mathrm{~h}$ & $4 \mathrm{~h}$ & \\
\hline 111 & NP_814413 & Oligoendopeptidase F & Proteolysis & 260 & 10 & 1.1 & 1.5 & $8.76 \times 10^{-5}$ \\
\hline 236 & NP_816048 & Elongation factor Ts & Protein biosynthesis & 335 & 43 & 4.1 & 2.1 & 0.003 \\
\hline 237 & ZP_05425197 & $\begin{array}{l}\text { Ornithine } \\
\text { carbamoyltransferase }\end{array}$ & Transferase activity & 1126 & 74 & 1.7 & -1.6 & 0.023 \\
\hline 155 & NP_371072 & Elongation factor $\mathrm{Tu}$ & Protein biosynthesis & 281 & 15 & 2.3 & 1.0 & 0.033 \\
\hline 314 & NP_814897 & $\begin{array}{l}\text { Fructose-bisphosphate } \\
\text { aldolase }\end{array}$ & $\begin{array}{l}\text { Fructose } 1,6 \text {-bisphosphate } \\
\text { metabolic process }\end{array}$ & 387 & 33 & 1.4 & -1.6 & 0.037 \\
\hline 147 & NP_815077 & $\begin{array}{c}\text { Dihydrolipoamide } \\
\text { dehydrogenase }\end{array}$ & $\begin{array}{l}\text { Flavin adenine dinucleotide } \\
\text { binding }\end{array}$ & 683 & 45 & 2.3 & -1.1 & 0.039 \\
\hline 333 & NP_814010 & $\begin{array}{l}\text { 30S ribosomal protein } \\
\text { S3 }\end{array}$ & Translation & 221 & 23 & 2.0 & -1.1 & 0.044 \\
\hline 78 & NP_371071 & Elongation factor $G$ & Protein biosynthesis & 362 & 16 & 1.3 & -3.2 & 0.048 \\
\hline 340 & NP_815638 & $\begin{array}{l}\text { Triosephosphate } \\
\text { isomerase }\end{array}$ & Glycolysis & 324 & 39 & 1.9 & -1.3 & 0.055 \\
\hline 294 & YP_002633557 & $\mathrm{ABC}$ transporter & ATP-binding & 404 & 25 & 1.5 & 2.7 & 0.057 \\
\hline 417 & 1FU0_A & $\begin{array}{l}\text { The phosphoserine } 46 \\
\text { Hpr }\end{array}$ & Phosphotransferase system & 98 & 13 & 1.7 & 1.0 & 0.059 \\
\hline
\end{tabular}

decline in activity by 60 min may indicate a loss in cell function or death.

Proteomic analysis revealed an increase in expression of a range of proteins following exposure of $S$. aureus cells to $\operatorname{Ag}(\mathrm{I})$ ions however a number of these proteins had declined in expression by $4 \mathrm{~h}$. At the $1 \mathrm{~h}$ time point, there was an increase in the expression of elongation factors Ts, Tu and $\mathrm{G}$ by 4.1-, 2.3- and 1.3-fold, respectively, but these subsequently decreased in relative expression by $4 \mathrm{~h}$. Kaakoush et al. (2008) also found that the elongation factors Tu and $\mathrm{G}$ of Campylobacter jejuni were upregulated as a result of exposure to $\mathrm{Cd}$ (II) ions. The present results using $\operatorname{Ag}(\mathrm{I})$ ions are interesting since elongation factors are required for extending the polypeptide chain in protein biosynthesis which is essential for microbial growth and development (Berisio et al. 2010), and suggests that additional protein biosynthesis occurs in response to metal ion exposure (Kaakoush et al. 2008).

Fructose-bisphosphate aldolase and triosephosphate isomerase in the $\operatorname{Ag}(\mathrm{I})$-treated $S$. aureus cells were found to be increased in expression at $1 \mathrm{~h}$ and decreased in expression by $4 \mathrm{~h}$. Fructose bisphosphate aldolase has previously been reported to be increased in expression in caspofungin-treated C. albicans cells, where it was postulated to be contributing to a stronger immune response (Kelly and Kavanagh 2010). With the $\mathrm{AgNO}_{3}$-treated $\mathrm{S}$. aureus cells, a third protein, dihydrolipoamide dehydrogenase, was increased in expression by 2.3 -fold at $1 \mathrm{~h}$ but this decreased to -1.1 -fold at $4 \mathrm{~h}$.

Proteins involved in the virulence of $S$. aureus included an $\mathrm{ABC}$ transporter protein (spot 294) and phosphoserine $46 \mathrm{Hpr}$ (spot 417). S. aureus cells responded to $\mathrm{AgNO}_{3}$ exposure by significantly increasing the expression of the $\mathrm{ABC}$ transporter at 1 and $4 \mathrm{~h}$ (spot 294; 1.5 - and 2.7-fold, respectively), suggesting an increase in the efflux of xenobiotics produced as a result of exposure to the $\operatorname{Ag}(\mathrm{I})$ ion. Phosphoserine 46 HPr plays an important role in the carbon catabolite repression system (Gorke and Stulke 2008) and its expression was increased by 1.7 -fold at $1 \mathrm{~h}$ before returning to basal level at $4 \mathrm{~h}$.

Oligoendopeptidase F (spot 111), which is involved in proteolysis (Jenal and Hengge-Aronis 2003), also increased in expression by 1.5 -fold at $4 \mathrm{~h}$. This protein is thought to contribute to the virulence of this organism since Group A Streptococci has been shown to evade the host immune response by disrupting the recruitment of phagocytic cells through the action of a serine endopeptidase (Voyich et al. 2004). 
The results presented here indicate that exposure of S. aureus to the $\mathrm{MIC}_{80}$ value of $\mathrm{AgNO}_{3}$ leads to a transient increase in the activity of SOD, GLR and catalase after $30 \mathrm{~min}$ and an increase in expression of a range of proteins having diverse functions after $1 \mathrm{~h}$ exposure. By $60 \mathrm{~min}$, the level of enzymatic activity has declined, and by $4 \mathrm{~h}$ the expression of many of the proteins has returned to basal levels or below. The significance of these results is that short term exposure to sub-lethal concentrations of $\mathrm{AgNO}_{3}$ induces the bacterium to mount a response to counteract the effects of $\mathrm{Ag}(\mathrm{I})$ ions (e.g. increased enzymatic activity, elevated expression of elongation factors). Prolonged exposure to $\mathrm{AgNO}_{3}$ leads to reduced enzymatic activity and protein expression indicating that the $\operatorname{Ag}(\mathrm{I})$ ions can overwhelm the cell and cause its demise. Initially, S. aureus actively attempts to limit the damage imposed by exposure to the $\mathrm{Ag}(\mathrm{I})$ ion.

Acknowledgments This work was supported by funding provided by the Higher Education Authority of Ireland through the Programme for Research in Third Level Institutions Cycle 4.

\section{References}

Adams AP, Santschi EM, Mellencamp MA (1999) Antibacterial properties of a silver chloride-coated nylon wound dressing. Vet Surg 28:219-225

Atiyeh BS, Costagliola M, Hayek SN, Dibo SA (2007) Effect of silver on burn wound infection control and healing: review of the literature. Burns 33:139-148

Berisio R, Ruggiero A, Vitagliano I (2010) Elongation factors EFIA and EF-Tu: their role in translation and beyond. Israel J Chem 50:71-79

Carbon RT, Lugauer S, Geitner U, Regenfus A, Böswald M, Greil J, Bechert T, Simon S-I, Hümmer HP, Guggenbichler J-P (1999) Reducing catheter-associated infections with silver-impregnated catheters in long-term therapy of children. Infection 27:69-73

Castellano JJ, Shafii SM, Ko F, Donate G, Wright TE, Mannari RJ, Payne WG, Smith DJ, Robson MC (2007) Comparative evaluation of silver-containing antimicrobial dressings and drugs. Int Wound J 4:114-122

Clements MO, Watson SP, Foster SJ (1999) Characterization of the major superoxide dismutase of Staphylococcus aureus and its role in starvation survival, stress resistance, and pathogenicity. J Bacteriol 181:3898-3903

Cortese-Krott MM, Munchow M, Pirev E, Hessner F, Bozkurt A, Uciechowski P, Pallua N, Kroncke KD, Suschek CV (2009) Silver ions induce oxidative stress and intracellular zinc release in human skin fibroblasts. Free Radical Biol Med 47:1570-1577

Dasgupta MK (1994) Silver peritoneal catheters reduce bacterial colonization. Adv Perit Dial 10:195-198
Foster JG, Hess JL (1980) Response of superoxide dismutase and glutathione reductase activities in cotton leaf tissue exposed to an atmosphere enriched in oxygen. Plant Physiol 66:487-488

García-Lara J, Masalha M, Foster SJ (2005) Staphylococcus aureus: the search for novel targets. Drug Discovery Today 10:643-651

Gorke B, Stulke J (2008) Carbon catabolite repression in bacteria: many ways to make the most out of nutrients. Nature Rev Microbiol 6:613-624

Jenal U, Hengge-Aronis R (2003) Regulation by proteolysis in bacterial cells. Curr Opin Microbiol 6:163-172

Kaakoush NO, Raftery M, Mendz GL (2008) Molecular responses of Campylobacter jejuni to cadmium stress. FEBS J 275:5021-5033

Kelly J, Kavanagh K (2010) Proteomic analysis of proteins released from growth-arrested Candida albicans following exposure to caspofungin. Med Mycol 48:598-605

Larsen B, White S (1995) Antifungal effect of hydrogen peroxide on catalase-producing strains of Candida spp. Infect Dis Obst Gynecol 3:73-78

Lok CN, Ho CM, Chen R, He QY, Yu WY, Sun HZ, Tam P, Chiu JF, Che CM (2006) Proteomic analysis of the mode of antibacterial action of silver nanoparticles. J Proteome Res 5:916-924

Monafo WW, Freedman B (1987) Topical therapy for burns. Surg Cli North Am 67:133-145

Olsen ME, Wright JB, Lam K, Burrell RE (2000) Healing porcine donor sites covered with silver-coated dressings. Eur J Surg 166(6):486-489

Park HJ, Kim JY, Kim J, Lee JH, Hahn JS, Gu MB, Yoon J (2009) Silver-ion-mediated reactive oxygen species generation affecting bactericidal activity. Water Res 43: 1027-1032

Percival SL, Bowler PG, Russell D (2005) Bacterial resistance to silver in wound care. J Hospit Infect 60:1-7

Pichon C, Felden B (2005) Small RNA genes expressed from Staphylococcus aureus genomic and pathogenicity islands with specific expression among pathogenic strains. Proc Natl Assoc Sci USA 102:14249-14254

Rowan R, McCann M, Kavanagh K (2010) Analysis of the response of Candida albicans cells to Silver(I). Med Mycol 48:498-505

Shevchenko A, Tomas H, Havlis J, Olsen JV, Mann M (2006) In-gel digestion for mass spectrometric characterization of proteins and proteomes. Nat Protoc 1:2856-2860

Ulker E, Oncul O, Karagoz H, Celikoz B, Cavuslu S (2005) Comparison of silver-coated dressing (Acticoat) chlorhexidine acetate $(0.5 \%)$ (Bartiglas) and silver sulfadiazine $1 \%$ (Silverdin) for topical antibacterial effect in Pseudomonas aeruginosa contaminated full thickness burn wounds in rats. J Burn Care Rehabil 26:430-433

Voyich JM, Musser JM, Deleo FR (2004) Streptococcus pyogenes and human neutrophils: a paradigm for evasion of innate host defense by bacterial pathogens. Microbes Infect 6:1117-1123

Wright JB, Lam K, Burrell RE (1998) Wound management in an era of interesting bacterial antibiotic resistance. A role for topical silver treatment. Am J Infect Control 26:572-577 